\title{
IMPROVING FARM PRACTICES AND PRODUCTIVITY THROUGH TRAINING NEEDS ASSESSMENT OF SUGARCANE FARMERS: THE CASE OF DAVAO MILL DISTRICT, THE PHILIPPINES
}

\author{
aMarietta Dina Padilla-Fernandez*, bJoseph P. Gonzales, cMiguel J. C. Mamauag \\ a Department Chief Agriculturist, Extension Services Division, Sugar Regulatory Administration. \\ b Training Specialist II, Extension Services Division, Sugar Regulatory Administration. \\ c Project Development Officer (Statistician), Extension Services Division, Sugar Regulatory Administration.
}

\section{ART ICLE I N F O}

\section{Article history}

Received: April 17, 2020

Revised: July 22, 2020

Accepted: August 22, 2020

\section{Keywords}

Training needs

Sugarcane production, Philippines

\section{A B S T R A C T}

The need to improve the farm practices and productivity in the Davao mill district was examined through Training Need Assessment. The aim is to develop a well-designed and need-based training program for its sugarcane farmers. A two-stage stratified random sampling technique was employed to select 112 respondents. A wellstructured questionnaire was used, and data were analyzed using Likert Scale and multiple regression analysis. The areas of training needs identified for sugarcane production were on the application/computation of chemical fertilizer, soil fertility management, selection of varieties, seizing fertilization and irrigation before harvesting, managing disease control and designing a weed control program. The information on the processing of sugar, the current situation of the sugarcane industry in the domestic and world markets, and farm plan and budgeting were also identified. For other crop production, the training needs were on swine, corn production and poultry raising. Farmers also need training on product quality and packaging and marketing for muscovado, vinegar and wine making for their source of livelihood. The relational analysis showed a positive and significant relationship between age and access to high yielding varieties with training needs expressed by the farmers on sugarcane production. Training could be more effective by targeting older farmers as they seemed to be more receptive to technology although young farmers also need to be trained due to succession in sugarcane farming. The study recommends assessing the interventions given to the Davao MDDC particularly the nursery farms under the Rapid Propagation and Distribution Program of SRA especially on the accessibility of HYV seeds. It also recommends for SRA and the Davao MDDC to increase extension contact and develop training modules and re-orient training schedules with training needs expressed by the farmers to improve the farm practices and productivity in the study area.

Corresponding Author: Marietta Dina Padilla-Fernandez

Email: dina_padilla_fernandez@yahoo.com

(C) The Author(s) 2020.

\section{INTRODUCTION}

Problems that inversely influence farm productivity are numerous which vary from the use of low yielding varieties, improper application of cultural practices, the natural calamities such as typhoon, drought, pests and diseases outbreak, lack of farmers' training, and ageing farming population. To increase farm productivity and to minimize the effect of calamities, farmers have to be 
convinced to change to certain improved production technologies. In the production of sugarcane, these technologies include among others, the use of farm machines, soil and water management and pest/disease control measures. Convincing farmers to use these production technologies has been a challenge to the Philippine sugarcane industry.

The study was conducted in the Davao mill district which was purposively selected being one of the lowest sugar producing districts in the country. The district's average productivity is 38.42 tons cane per hectare (TC/HA) while in terms of sugar, 73.25 per 50 kilo bag/hectare $(\mathrm{LKg} / \mathrm{HA})$. The national average is 56.03 TC/HA and 103.62 LKg/HA (SRA Crop Estimation Report (2020). The district is located in the Mindanao island, the second largest island in the Philippines which is situated in the southern part of the country. It covers 3 provinces covering 17 municipalities with around 9,226 hectares of sugarcane land and approximately 3,275 farmers. The lone mill employs around 300-400 workers (DMDR, 2019). Evidently, many people are directly and indirectly dependent on sugarcane crop for their economic existence making it as one of the most important cash crops in Mindanao. In view of the vital contribution and role of the industry to the island's economy, the sugarcane farming must be given proper support by the government for the farmers to improve their productivity significantly.

Extension delivery in the district is essentially driven by both private and public sectors since 1992 . The private sector- Davao Mill District Development Committee (DMDDC) which serves as the focal point in the development of the district along with the public sectorSugar Regulatory Administration (SRA) have been giving extension and training services to the farmers. They conduct demonstration farms on improved varieties, establish nursery farms and continuously distribute planting materials, provide fertilizer and tractor services at subsidized costs and conduct trainings/seminars especially to small sugarcane farmers. Yet, despite these interventions, the mill district's productivity performance remains below par. The average farm productivity of the smaller farm size (less than 5 hectares) is way below the district productivity level. Even the biggest farm size (above 100 hectares), its average farm productivity is just a little bit higher than the mill district's average (Ibid, 2019).
One way to increase agricultural productivity is through technology adoption and proper farm practices by farmers (The World Bank Report, 2019). Technology adoption, however, is a broad concept. It is affected by the dissemination and application at the farm level, education, training, advice and information which form the basis of farmers' knowledge (Wageningen Workshop Proceedings, 2000). Chi and Yamada (2002) examined the factors affecting farmers' adoption of technologies in the farming system in OMon District, Mekong Delta and observed that farmers' change in the use of technology is influenced by technical dissemination such as technical training, meetings and oral transmission. Nakano et. al. (2018) dissected the technology dissemination pathways among smallholder rice producers within a rural irrigation scheme in Tanzania by comparing the performance of the three categories of farmers: key farmers, who receive intensive pre-season training at a local training center; intermediate farmers, who are trained by the key farmers; and other ordinary farmers. They found that the ordinary farmers who were a relative or residential neighbour of a key or intermediate farmer were more likely to adopt new technologies than those who were not. As a result, while the key farmers' technology adoption rates rose immediately after the training, those of the non-trained ordinary farmers caught up belatedly. As the technologies disseminated, the paddy yield of the key farmers increased higher than the yield of the ordinary farmers. It can be inferred that once farmers bring production technologies into practice; they can further diffuse to other farmers thereby improving the productivity and production of the other members of farming community.

Agricultural training is a potentially effective method to diffuse relevant new technologies (Nakano et al., 2018; Tambi, 2019). Shibu and George (2013) as cited in Raza et al. (2017)defined training as an organized activity designed to enhance the knowledge, skill and competencies of a person for improving his/her performance. While Adesoji et al. (2006) defined training as an essential resource, which will direct knowledge and skill towards production. In short, training provides farmers with the knowledge and skills they need in using the new technology to enhance their farm production and productivity.

The gap between the present status and desired status may indicate problems that in turn can be translated 
into a training need (JICA, 2016). One method to determine if a training need is required is the Training Needs Assessment (TNA). It identifies the area of farmers' interest and determines the priority of changes in knowledge and skill (Sajeev et al. (2012) hence one can design and develop the curriculum that can best suit to the existing "real" conditions of farmers. Thus, training needs assessment has to be carried out to design relevant and need-based training programs that can accommodate changes over time. A Training Needs Assessment acts as an integral guide to developing programs so that appropriate content is generated (Okwoche et al. (2015).

The impact of agricultural training on farm productivity is noteworthy. As examined by Ibitoye and Onimisi (2013) on farmers who are in poultry production in Kogi State, Nigeria, they found that training significantly improved poultry production practices through better adaptation of new techniques. Hence, they strongly recommended that farmers should be regularly trained by the extension agents. Noor and Dola (2011) examined the impact of training on farmers' perception and performance on Malaysian livestock farmers and concluded that training provided to the farmers has not only helped them improve their individual capabilities, but more importantly, boost their morale and motivation that clearly contributed to their positive performance level. In the Philippines, Padilla-Fernandez and Nuthall (2001a) explored the causes of farmers' efficiency in the production of sugarcane in Central Negros and found that productivity increased as farmers become more educated and well-trained. While considering these issues in mind, the study perceived that farm practices and productivity in sugarcane farming could be enhanced on a well-designed and need-based training. However, no research has been conducted regarding Training Need Assessment for sugarcane farmers in the country. Therefore, the study aimed to achieve the following specific objectives:

a) To identify the training needs of sugarcane farmers that can be used in the planning of future training programs to improve the farm practices and productivity in sugarcane farming in the Davao mill district.

b) To identify important variables to be considered when organizing training program for sugarcane farmers in the Davao mill district.

c) To examine the socio-economic characteristics of sugarcane farmers in the Davao mill district and relationship with their training needs.

\section{Scope and Limitation of the Study}

For the study to be manageable and meaningful, the following limitations were established:

a) The study was intended for sugarcane farmers of the Davao mill district only.

b) The calculation of the sample size was based on the cost and time invested.

c) Only few socio-economic characteristics were selected for investigation.

d) The study considered the influence of socioeconomic characteristics of farmers to the training need in sugarcane production only in response to the objective(a) set in this paper. The training needs for other crop production, other sources of livelihood, production technology and sugar related information and business management were also regressed with the socio-economic characteristics however, these variables did not improve the model, hence, were excluded.

\section{METHODOLOGY}

The Davao mill district has three provinces namely, Davao del Sur, General Santos and Sarangani with 17 municipalities. A two-stage stratified random sampling technique was employed. First, five municipalities namely, Hagonoy, Kiblawan, Matanao (Davao del Sur), Malungon (Sarangani) and Gensan (General Santos) were selected being the biggest sugarcane producing municipalities in the provinces. Secondly, from the Davao Mill District Planters' Directory for Crop Year 2016-17, farmers were classified according to farm size, namely: less 5 hectares; less than 10; less than 25; and less than 50 . The size of the sample was determined using the simplified formula for $\mathrm{n}$ in sampling for proportions given by Cochran (1977) with the acceptable error being set at 15 per cent. Around 22-23 sugarcane farmers in each municipality were randomly selected across farm size to reach a total of 112 respondents. Only a few respondents were replaced due to unavailability and the replacements were taken from the same farm size and location.

Data collection from randomly selected respondents was done using pre-tested structured questionnaire through the personal interview method. The questionnaires were pre-tested on a sample of farmers 
in the study area. The duration of data collection was from October 9 to 15, 2019. This was implemented with 20-30 farmers at a time, with five facilitators supporting the process and assisting illiterate farmers. Survey respondents were assured of the confidentiality of their responses.

Farmers were requested to self-assess their personal knowledge (competence) on different areas of training needs and rate its importance. Respondents' assessment of the importance of the training areas was measured on a three-point Likert-type scale with response options, from not needed to most needed. Respondents were required to place a 'tick' in the relevant response category. Besides closed questions, additional space for other answers or remarks was also included.

The major training needs components identified for the study were sugarcane production, and other crops such as rice and corn production, small and big ruminants, poultry and swine. To improve the quality of the respondents' other livelihood sources (sugar byproducts), training on product quality, packaging and post-production needs were identified. Training needs on specific production technology such as soil management for sugarcane growing, effect of soil $\mathrm{pH}$ on plant nutrients, best management practices for fertilization and etc. were also determined. Training on farm plan and budgeting, record keeping, access to credit and information on the world of sugar which would support farmers' business management were also sought. The venue of training, time and methods were also assessed in order of preference that ranged from not preferred to most preferred. This is for the future training program to be more effective and efficient.

Data from the study were analyzed using frequency distribution, percentages and mean scores. A mid-point was obtained from the 3-point Likert type scale of highly needed $=3$, fairly needed $=2$ and not needed $=1$. Thus: $3+2+1=6 / 3=2$. 0 . Any mean score of 2.0 and above implies needed training while below 2.0 suggests that it is not needed.

Multiple regression analysis was used to test the hypothesis to determine the socio-economic factors influencing the training needs of sugarcane farmers in the study area.

Multiple Linear Regression Model is as follows:

$\mathrm{Y}=\alpha+\beta 1 \mathrm{X} 1+\beta 2 \mathrm{X} 2+\cdots+\beta \mathrm{kXk}+\varepsilon$
Where,

$\mathrm{Y}$ is the Mean counts of training needed by sugarcane farmers.

$\mathrm{X} 1, \mathrm{X} 2, \ldots \mathrm{Xk}$ are the socio-economic characteristics of the sugarcane farmers.

$\alpha, \beta 1, \beta 2, \ldots, \beta \mathrm{k}$ are population coefficients that need to be estimated using sample data.

$\varepsilon$ is the error term.

\section{Research Hypotheses}

The null hypothesis for the research was that there is no relationship between some selected socio-economic characteristics of the sugarcane farmers and their training needs in sugarcane farming against the alternative hypothesis that there is relationship.

\section{Empirical Literature Review}

Agricultural education and extension have relation with farm productivity and efficiency (Padilla-Fernandez and Nuthall (2001b); Ahmad et al. (2007), farm management (Kilpatrick (2000), technology adoption (Huluka and Negatu (2016) and other related factors that need improvement to achieve agricultural development. These studies confirmed the positive effects of agricultural training hence it is worth determining its impact on sugarcane production in the Philippines. However, Training Needs Analysis should have been identified first for curriculum development which is the most important part in a training program.

Adesoji et al. (2006) assessed the training needs of Fadama farmers for future agricultural extension development in Osun state, Nigeria. Areas of training needs identified include: chemical control of insect pest, use of appropriate chemical and correct dose of application; appropriate herbicide to be used to reduce drudgery and storage of Fadama produce. The study concluded that extension agents and agencies should design regular training programmes for Fadama farmers in the area of deficiencies identified and strengthen Fadama associations such that tripartite problems of lack or high cost of inputs, lack of starting and operating capital and Fadama land could be reduced/solved.

Sajeev et al. (2012) investigated the training needs of farmers and rural youth in Manipur State, India. Farmers sought maximum trainings on integrated farming systems, integrated pest and disease management and technologies for soil and water conservation. Nursery management topped the list under horticulture while 
training with respect to rearing of piggery was the most important one under animal sciences. Income generating activities for empowerment of rural women, formation and maintenance of SHGs and training on small scale processing and value addition were also in high demand. The KVKs have to re-orient their trainings based on these findings to reduce the existing technological and adoption gap among the farmers in Manipur. Kshash (2016) assessed the training needs of rice farmers in Mahanawiyah District, AL-Qadisiya Province, Iraq. Findings revealed that majority of the farmers had medium level of training needs. Weed management, disease and pest control, seed and seedling were the top most training needs of the farmers and the least training need was land preparation. The variables educational attainment, area cultivated with rice, and annual revenue from rice cultivation had positive and significant association with the training needs. Past studies had earlier shown that it is important to determine the training needs of farmers for agricultural development. Training needs thus identified knowledge and skill gap between what is and what ought to be in the execution of specific tasks towards the achievement of set goals and objectives. It can be considered a condition in which there is a difference between "what is and what should be" (FAO, 1991 as cited in Oyeyinka and Bolarinwa (2015).

\section{RESULTS AND DISCUSSIONS}

\section{Demographic Characteristics of the Respondents}

Table 1 shows the profile of the respondents in the survey areas. Majority (63.39\%) of the respondents were men, which tends to mirror the gender composition of sugarcane farming in the country. Majority (88\%) were married. Around $54 \%$ of the respondents belonged to the 50 years old and above category. Mean age is 53 years old. While looking at the educational status of the respondents, results revealed that majority (around $52 \%$ ) of them were literate (up to high school), elementary, $27 \%$ and only a few (13\%) reached college. Only $5 \%$ have no formal education. Mean years in school is 7.43. These suggest that many farmers in the target groups were functionally literate which may impact on their ability to access different types of training and information. The low percentage of those with formal education may adversely influence the respondents' change to innovations in sugarcane production. However, this may be compensated by the length of farming experience (11-20 years) by majority (45.54\%) of the respondents and around 31\% with more than 20 years of farming experience. Mean farming experience is 19 years.

Table 1. Profile of the respondents' farmers in the survey areas.

\begin{tabular}{lll}
\hline Characteristics & Frequency & $\%$ \\
\hline Sex & & \\
\hline Male & 71 & 63.39 \\
Female & 41 & 36.61 \\
\hline Marital Status & & \\
\hline Married & 98 & 87.50 \\
Single & 5 & 4.46 \\
\hline Age (years) & & \\
\hline Less than 30 & 2 & 1.79 \\
$31-40$ & 17 & 15.18 \\
$41-50$ & 33 & 29.46 \\
50 above & 60 & 53.57 \\
\hline Years in School & & \\
\hline No formal education & 5 & 4.46 \\
$1-6$ & 50.79 \\
$7-10$ & 30 & 26.79 \\
$11-14$ & 58 & 51.79 \\
\hline
\end{tabular}




\begin{tabular}{|c|c|c|}
\hline 15 or more & 4 & 3.57 \\
\hline 10 and below & 26 & 23.21 \\
\hline \multicolumn{3}{|l|}{ Farming experience (years) } \\
\hline $11-20$ & 51 & 45.54 \\
\hline Above 20 & 35 & 31.25 \\
\hline \multicolumn{3}{|l|}{ Household size } \\
\hline 2 and below & 16 & 14.29 \\
\hline 3 & 16 & 14.29 \\
\hline 4 or more & 80 & 71.43 \\
\hline \multicolumn{3}{|l|}{ Farm size (hectares) } \\
\hline 5 and below & 45 & 40.18 \\
\hline Less than 10 and greater than 5 & 38 & 33.93 \\
\hline Less than 25 and greater than 10 & 20 & 17.86 \\
\hline Greater than 25 & 9 & 8.04 \\
\hline \multicolumn{3}{|l|}{ Tenurial status } \\
\hline Private-leased & 59 & 31.89 \\
\hline Owned \& individually managed & 78 & 42.16 \\
\hline CLOA holder \& individually managed & 48 & 25.95 \\
\hline \multicolumn{3}{|l|}{ No. of Trainings in the Past 5 years } \\
\hline None & 45 & 40.18 \\
\hline $1-3$ & 21 & 18.75 \\
\hline $4-6$ & 46 & 41.07 \\
\hline Membership in Cooperatives/ Associations & 29 & 25.66 \\
\hline Access to Extension Services & 50 & 63 \\
\hline Ratio of YES over NONE & 0.79 & \\
\hline Access to improved varieties & 62 & 51 \\
\hline Ratio of YES over NONE & 1.22 & \\
\hline Access to tractor services & 49 & 64 \\
\hline Ratio of YES over NONE & 0.77 & \\
\hline
\end{tabular}

Table 1 also revealed that majority (40\%) of the respondents were small landholders. Majority (80\%) of the respondents had four or more than four family members as well. Result on tenurial status showed that majority (42\%) of the respondents' farms are owned and individually managed while around $32 \%$ of the respondents leased their farms from the private owners; few (4\%) also leased from some Certificate of Land Ownership Award (CLOA) holders.

Majority (40\%) of the respondents do not have trainings for the past 5 years although around $41 \%$ of the respondents have 4-6 number of trainings attended. The study also showed that only around $26 \%$ of the respondents were members of local farmers' organizations. Majority were non-members since they mill directly to the sugar mill which takes care of their farming needs. Half of the respondents have access to extension services, improved varieties and tractor services.

\section{Training needs}

The training needs of the farmers in all areas except in other crops and sources of livelihood are presented in the form of average weighted mean scores. Weighted Scores were ranked within each area and the rankings were identified as training needs of the respondents, 1 being the most needed. For other crops and sources of livelihood, the training needs are presented in the form 
of the ratio of the needed over not needed. The following are the areas where there are high training needs among the respondents.

The highest-ranking training needs, as determined by the average weighted mean score is in specific production technology and sugar-related information, followed by business management (see Table 2). Training on sugarcane production was the lowest- ranked needs as expressed by the respondents. This is due to their familiarity with sugarcane production (the mean farming experience of the respondents is 19 years). Between the training on the production of other crops (rice, corn, cattle, etc.) and other livelihood projects (sugarcane-based such as muscovado, vinegar and wine making), the respondents put higher need to the latter.

Table 2. Training needs of respondents in all areas.

\begin{tabular}{|c|c|c|c|c|c|}
\hline \multirow{2}{*}{ Area } & \multicolumn{3}{|c|}{ Total } & \multirow{2}{*}{$\begin{array}{c}\text { Average } \\
\text { Weighted } \\
\text { Mean Score }\end{array}$} & \multirow{2}{*}{ Rank } \\
\hline & Not needed & Fairly needed & Most Needed & & \\
\hline Sugarcane farm management & 438 & 1533 & 2509 & 2.46 & 3 \\
\hline $\begin{array}{l}\text { Specific Production Technology \& } \\
\text { Sugar Related Information }\end{array}$ & 26 & 122 & 636 & 2.78 & 1 \\
\hline \multirow[t]{3}{*}{ Business Management } & 19 & 169 & 484 & 2.69 & 2 \\
\hline & \multicolumn{2}{|c|}{ Total } & Ratio & & \\
\hline & Not Needed & Needed & $>1)$ & & \\
\hline Other crops (rice, corn, cattle, etc.) & 377 & 295 & 0.78 & & 2 \\
\hline Other source of livelihood & 294 & 266 & 0.90 & & 1 \\
\hline
\end{tabular}

\section{Sugarcane production}

Looking in more details at the training needs of the respondents in sugarcane production, the survey showed that training on fertilizer and soil fertility management were the most sought-after by the respondents, followed by selection of varieties of sugarcane, and training on seizing irrigation and fertilizer before harvesting (Table 3). Training on managing disease using chemicals and designing weed control program closely followed. Training was least sought for irrigation method, how to prepare the field and time of planting.

Table 3. Training on selection of varieties, planting time, irrigation and fertilizer.

\begin{tabular}{lcccccccc}
\hline \multicolumn{1}{c}{ Area } & $\mathrm{N}$ & $\begin{array}{c}\text { Not } \\
\text { needed }\end{array}$ & $\begin{array}{c}\text { Fairly } \\
\text { needed }\end{array}$ & $\begin{array}{c}\text { Most } \\
\text { Needed }\end{array}$ & $\begin{array}{c}\text { Score } \\
\text { Meanted } \\
\text { Score }\end{array}$ & $\begin{array}{c}\text { Rank } \\
\text { Top } \\
10\end{array}$ \\
\hline 1. Selection of land for sugarcane growing & 112 & 18 & 40 & 54 & 260 & 2.32 & 24 \\
\hline $\begin{array}{l}\text { 2. How to prepare the field } \\
\text { a) Mechanized plowing }\end{array}$ & 112 & 22 & 43 & 47 & 249 & 2.22 & 27 \\
b) Mechanized harrowing & 112 & 22 & 45 & 45 & 247 & 2.21 & 28 \\
$\quad$ c) Furrow layout & 112 & 25 & 52 & 35 & 234 & 2.09 & 31 & \\
\hline 3. Planting time & 112 & 25 & 46 & 41 & 240 & 2.14 & 30 & \\
\hline 4. Selection of variety & & & & & & & & 7 \\
a) High yielding & 112 & 11 & 23 & 78 & 291 & 2.60 & 7 & 7 \\
b) Early, mid and late maturing & 112 & 16 & 36 & 60 & 268 & 2.39 & 21 & \\
c) Pest/disease resistant ability & 112 & 14 & 27 & 71 & 281 & 2.51 & 13 & 9 \\
d) Drought/water resistant & 112 & 15 & 21 & 76 & 285 & 2.54 & 9 & 9 \\
\hline
\end{tabular}




\begin{tabular}{|c|c|c|c|c|c|c|c|c|}
\hline \multicolumn{9}{|l|}{ 5. Planting method } \\
\hline a) Dry \& wet season & 112 & 11 & 37 & 64 & 277 & 2.47 & 16 & \\
\hline b) Whole stalk, seed pieces, etc & 112 & 11 & 42 & 59 & 272 & 2.43 & 18 & \\
\hline \multicolumn{9}{|l|}{ 6. Irrigation method } \\
\hline a) Drip irrigation & 112 & 12 & 46 & 54 & 266 & 2.38 & 22 & \\
\hline b) Furrow irrigation & 112 & 15 & 41 & 56 & 265 & 2.37 & 23 & \\
\hline c) Sub-surface irrigation & 112 & 20 & 43 & 49 & 253 & 2.26 & 26 & \\
\hline \multicolumn{9}{|l|}{ 7. Fertilizer management } \\
\hline a) Types of chemical fertilizers & 112 & 3 & 23 & 86 & 307 & 2.74 & 1 & 1 \\
\hline b) Content in chemical fertilizers & 112 & 4 & 22 & 86 & 306 & 2.73 & 2 & 2 \\
\hline c) Method of fertilizer application & 112 & 4 & 26 & 82 & 302 & 2.70 & 4 & 4 \\
\hline d) Fertilizer computation & 112 & 6 & 19 & 87 & 305 & 2.72 & 3 & 3 \\
\hline e) Partitioning and time of application & 112 & 7 & 26 & 79 & 296 & 2.64 & 6 & 6 \\
\hline \multicolumn{9}{|l|}{ 8. Managing Soil Fertility } \\
\hline a) Trash mulching & 112 & 3 & 41 & 68 & 289 & 2.58 & 8 & 8 \\
\hline $\begin{array}{l}\text { b) Application of mudpress- } \\
\text { dose/hectare }\end{array}$ & 112 & 5 & 26 & 81 & 300 & 2.68 & 5 & 5 \\
\hline \multicolumn{9}{|l|}{ 9. Managing Weeds } \\
\hline a) Cultural control & 112 & 6 & 47 & 59 & 277 & 2.47 & 16 & \\
\hline b) Biological control & 112 & 9 & 51 & 52 & 267 & 2.38 & 22 & \\
\hline c) Mechanical control & 112 & 8 & 49 & 55 & 271 & 2.42 & 19 & \\
\hline $\begin{array}{l}\text { d) Chemical control- types/time of } \\
\text { application }\end{array}$ & 112 & 12 & 34 & 66 & 278 & 2.48 & 15 & \\
\hline e) Organic herbicides & 112 & 14 & 51 & 47 & 257 & 2.29 & 25 & \\
\hline f) Designing weed control program & 112 & 7 & 39 & 66 & 283 & 2.53 & 10 & 10 \\
\hline \multicolumn{9}{|l|}{ 10. Managing Pests } \\
\hline a) Cultural control & 112 & 9 & 47 & 56 & 271 & 2.42 & 19 & \\
\hline b) Biological control & 112 & 10 & 46 & 56 & 270 & 2.41 & 20 & \\
\hline c) Mechanical control & 112 & 11 & 41 & 60 & 273 & 2.44 & 17 & \\
\hline d) Chemical control & 112 & 8 & 39 & 65 & 281 & 2.51 & 13 & \\
\hline \multicolumn{9}{|l|}{ 11. Managing Diseases } \\
\hline a) Cultural control & 112 & 9 & 35 & 68 & 283 & 2.53 & 11 & 10 \\
\hline b) Biological control & 112 & 7 & 42 & 63 & 280 & 2.50 & 14 & \\
\hline c) Mechanical control & 112 & 8 & 40 & 64 & 280 & 2.50 & 14 & \\
\hline d) Chemical control & 112 & 8 & 36 & 68 & 284 & 2.54 & 9 & 9 \\
\hline 12.Irrigation/drainage management & 112 & 30 & 32 & 50 & 244 & 2.18 & 29 & \\
\hline \multicolumn{9}{|l|}{ 13. Harvesting } \\
\hline a) Maturity signs & 112 & 3 & 48 & 61 & 282 & 2.52 & 12 & \\
\hline b) Maturity index & 112 & 4 & 46 & 62 & 282 & 2.52 & 12 & \\
\hline c) Time of seizing fertilizer & 112 & 3 & 40 & 69 & 290 & 2.59 & 8 & 8 \\
\hline d) Time of seizing irrigation & 112 & 3 & 45 & 64 & 285 & 2.54 & 9 & 9 \\
\hline
\end{tabular}

Under the fertilizer management, the type of fertilizer to use, its contents, computation, proper application and partitioning/time of application were the highly needs. Farmers know the importance of fertilizer however, they 
may not know the right timing, type, and amount of fertilizer to use. Urea is the most important nitrogenous fertilizer in sugarcane production, with the highest Nitrogen (N) content (about 46 percent), however, farmers usually settle for $18-46-0$ fertilizer which is cheaper without considering the $\mathrm{N}$ content of the fertilizer and the $\mathrm{N}$ requirement of the soil. PadillaFernandez and Nuthall (2001a) reported that sugarcane farmers in Central Negros, appears to apply NPK fertilizer in surplus. This resulted to a waste. Knowledge on the computation of fertilizer could help farmers identify which and how much fertilizer or right fertilizer/ combination to use.

The proper application of fertilizer is very crucial for farmers to realize the efficacy of fertilizer usage while minimizing the bad effects of improper application especially of the chemical fertilizer. In basal application, before planting the cane points, the applied fertilizer is covered with a thin layer of soil to prevent injury to the buds. However, most often, farmers immediately lay out the cane points instead of covering the fertilizer applied with soils. This is to immediately finish the job as payment is on a per hectare basis. While in top dressing, farmers usually place the fertilizer near the base of the plant for its easy absorption. Fertilizers should be applied 8-20 cms away from the base of the plant to avoid salt injury to the plant (Ang Tamang-Pagtutubuhan (2019).

Training on partitioning fertilizer and its time of application is also critical as this practice depends on the moisture content and the type of soil. Full dose is usually being practiced by the farmers to reduce the cost of fertilizer application. However, in sandy soil, this practice is not applicable. For light textured or sandy soil, split application of $\mathrm{N}$ and potassium $(\mathrm{K})$ fertilizers is recommended. When much rainfall is expected or on irrigated farms, the first dose is better applied after the first weeding. When not, much rain is expected, the first dose of fertilizer maybe applied at planting or ratooning as there are less chances of leaching and weed competition is minimum. Application of fertilizer during the peak of the dry season is not advisable, it will be better to apply the first dose at the onset of rain. In all instances, the second dose is best applied immediately after the last weeding before closing the field by the last hilling-up cultivation. All the fertilizers must be applied within 3 to 5 months after planting or ratooning (Ibid).

On the other hand, heavy - textured or clayey soils have high water and nutrient holding capacities and application of fertilizers maybe done in a single dose. Full dose of fertilizers is better applied after the first weeding during the early and late milling seasons when much rainfall is expected or on irrigated farms. Fertilization may be done at planting time or immediately after stubble-shaving of the ratoon crop during the early part of the dry season when there is still enough soil moisture to dissolve the applied fertilizer. Sugarcane crop established during the peak of the dry season will be better fertilized at the onset of the rainy season when unirrigated (Ibid).

Under the soil fertility management, the use of trash mulching and the application of mud press were the highly needs. Concern was raised regarding the degree of soil degradation that can occur under sugarcane production due to continuous cultivation. Farmers have thought that the most serious factor associated with soil degradation under sugarcane is the loss of soil fertility especially the organic matter. Trash mulching and the application of mud press improves soil properties. Trashes which are incorporated to the soil are decomposed into humus thus improving the fertility, texture and structure of the soil. Soil tilth is improved which decreases the need for tillage intensity, enhanced water infiltration and water retention. This allows sugarcane to tolerate drought especially during the El Niňo years (Mendoza et al. (2001).

For the selection of variety, training needs were put the drought/water resistant and high yielding varieties (HYVs). Majority of the respondents were aware of this improved technology and would even adopt it in order to cope with climate change. However, farmers lack knowledge in variety selection plus the fact that planting HYVs command more inputs and judicious appropriate cultural practices to maximize its potential hence, the need on training on such technology.

Training on seizing fertilizer and irrigation before harvesting were also regarded as the highly needs of the respondents. When farmers were informed that these practices could help increase sugar yield, they expressed interest on the topics. There are detrimental effects of these two practices when improperly applied. Excessive application of $\mathrm{N}$ fertilizer few months before harvesting is harmful to the crop as it prolongs vegetative growth thus, delays maturity and ripening, increases reducing sugar content in juice thus lowering juice quality and increases soluble $\mathrm{N}$ in juice affecting its clarification during the manufacturing of sugar. While seizing irrigation before 
harvesting induces maturity in sugarcane by reducing the rate of vegetative growth thus, forcing the conversion of total sugars to recoverable sucrose thus increases sucrose yields.

Only a few farmers are irrigating their farms. All they know is that when rain comes a few months/days before harvesting, their cane will surely have a much lower sugar yield.

Respondents have expressed the importance of an integrated weed control management since manual weeding is laborious and time consuming while chemical treatments must typically be administered several times to prevent the weed from re-establishing. Designing an integrated weed control management is economically efficient as it involves integration of cultural, manual, mechanical and chemical methods which are applied depending on the age of crop and available resources.

Training on disease management using chemicals was also expressed. Respondents realized that chemicals act very fast and when selected properly they are highly effective in eliminating the diseases of sugarcane however, respondents lack the knowledge and skills. For those respondents who do not want to use chemicals, they sought training in using cultural practices for disease management. These practices include planting of resistant varieties, using clean seedpieces by securing from disease-free nurseries and treating seedpieces with fungicide before planting to prevent smut. Moreover, practicing good farm hygiene to minimize the incidence of alternate hosts such as "talahib" and "aguingay", and destroying (rogue and burn infected stools) diseased crops in abandoned fields.

Most of the sugarcane farms in the Davao mill district are non-irrigated. In Digos City alone, Trondillo et al. (2019) found that of only $1,855.53$ hectares are highly suitable and 14,377.55 hectares are not suitable for pump irrigation system from open source (PISOs). This may be the reason why training in irrigation method was not given much importance by the respondents. Furthermore, less training need has been perceived for proper method of land preparation. Majority of the respondents practice custom plowing which is usually access through tractor rental service.

\section{Other crops (rice, corn, cattle, small ruminants, etc.) production}

Training needs on pig production was the most soughtafter, with 1.29 ratio of needed over not needed by the respondents expressing needs in training in this area (Table 4). This was followed by corn production, poultry and cattle production. Training needs on rice production was sought-after by few respondents. This may reflect their familiarity in rice production or others may not be producing it at all. Training on swine and poultry were also ranked as highly needs. Chickens and pigs are usually raised and sold by women and children, hence an important source of income for the family.

Table 4. Training needs of respondents in other crops (rice, corn, etc).

\begin{tabular}{lccccc}
\hline \multirow{2}{*}{ Area } & \multirow{2}{*}{$\mathrm{N}$} & \multicolumn{2}{c}{ Need } & Ratio of Needed Over & \multirow{2}{*}{ Rank } \\
\cline { 3 - 4 } & & & Not Needed & Needed & \\
1. Rice production & 112 & 74 & 38 & 0.51 & VI \\
2. Corn production & 112 & 56 & 56 & 1.00 & II \\
3. Cattle production & 112 & 66 & 46 & 0.70 & IV \\
4. Small ruminants production (Goat) & 112 & 69 & 43 & 0.62 & V \\
5. Poultry production & 112 & 63 & 49 & 0.78 & III \\
6. Swine production & 112 & 49 & 63 & 1.29 & I \\
\hline
\end{tabular}

\section{Other sources of livelihood (sugar by-products)}

To improve the quality of farmers' other livelihood activities such as food processing using sugar-based byproducts such as muscovado sugar, vinegar and wine making, the respondents were asked to assess their training needs on product quality, packaging and postproduction (marketing information and processing facilities). Training on the development of product quality appeared as the most important need, with 1.04 ratio of needed over not needed by the respondents (Table 5). This reflects the desire of the respondents for their products to be more competitive in the market. The respondents may have considered the potential, especially of the muscovado sugar, in the domestic and international markets due to the trend toward healthy lifestyles all over the world. This was followed by a need 
to have training in product packaging to protect their product from damage during transit and also as part of the promotional strategy. Training on better market information was also expressed as a need. Market information regarding demand and prices may encourage more farmers to engage in other income- generating livelihood projects especially in the production of muscovado sugar. Training on the processing facilities was the least need of the respondents, which may reflect the non-ownership so they don't need training on the said facilities.

Table 5. Training needs of respondents for other source of livelihood

\begin{tabular}{lccccc}
\hline \multirow{2}{*}{ Area } & & \multicolumn{3}{c}{ Need } & \\
\cline { 3 - 4 } & & Not needed & Needed & Ratio of Needed Over Not Needed & Rank \\
\hline 1. Product quality & 112 & 55 & 57 & 1.04 & I \\
2. Product packaging & 112 & 57 & 55 & 0.96 & II \\
3. Post-production needs & 112 & 62 & 50 & 0.81 & IV \\
a) Market information & 112 & 58 & 54 & 0.93 & III \\
b) Processing facilities & 112 & 62 & 50 & 0.81 & IV \\
\hline
\end{tabular}

Specific Production technology and sugar related information

The survey showed that training on sugar manufacturing was the most needed by the respondents (Table 6). Generally, only few people can enter the sugar mill to witness the processing of sugar. This is very critical for the farmers because the sugar recovery as reflected in the mill production report formed the basis of their proceeds. The production sharing system in the Philippines is 60:40 or 70:30, where the smaller share serves as the payment for processing the sugarcane. Such arrangement makes farmers speculate on the validity of the production report as being issued by the mill.

Table 6. Training needs of respondents in production technology.

\begin{tabular}{llllllll}
\hline Area & \multirow{2}{*}{$\begin{array}{l}\text { Not } \\
\text { Needed }\end{array}$} & $\begin{array}{l}\text { Fairly } \\
\text { Needed }\end{array}$ & $\begin{array}{l}\text { Most } \\
\text { Needed }\end{array}$ & Score & $\begin{array}{l}\text { Weighted } \\
\text { Mean Score }\end{array}$ & Rank \\
\hline 1. Soil Structure \& Texture for Sugarcane & 112 & 1 & 25 & 86 & 309 & 2.76 & IV \\
2. Soil pH \& Availability of Nutrients & 112 & 3 & 20 & 89 & 310 & 2.77 & III \\
3. Soil Acidity \& Application of Lime & 112 & 3 & 24 & 85 & 306 & 2.73 & V \\
4. Soil Nutrient (NPK) and its Mobility & 112 & 4 & 11 & 97 & 317 & 2.83 & II \\
5. Deficiency Symptoms of NPK & 112 & 7 & 13 & 92 & 309 & 2.76 & IV \\
6. How Sugar is Manufactured in the Mill & 112 & 3 & 8 & 101 & 322 & 2.88 & I \\
7. Sugar Regulation & 112 & 5 & 21 & 86 & 305 & 2.72 & VI \\
\hline
\end{tabular}

Soil nutrients and its mobility play a key role in plant nutrition. Sugarcane needs nutrients to be able to grow and produce biomass. The major nutrients (NPK) are usually lacking in the soil because sugarcane use large amounts for growth and survival. Thus, it is important for sugarcane farmers to know the NPK content of their soil, to determine how much N, P and/or K to be applied to optimize crop growth and yield. A soil test is applied to determine the nutrient available.

Knowing soil nutrient and its mobility is helpful in diagnosing plant nutrient deficiencies. Nitrogen is mobile and N-deficiency symptoms are first observed on older leaves. Leaf blades become uniformly pale-green to yellow. Phosphorus is also mobile. Older leaves become slender and blue green in color. Red or purple color may also be seen, particularly at tips and margins exposed to direct sunlight. Potassium is also mobile. Deficiency can result in "firing" (an orange or reddish-brown discoloration) on older leaves. Young leaves are generally all dark green (Ang Tamang Pagtutubuhan (2019). 
However, excessive application of $\mathrm{N}$ fertilizers is also detrimental as it increases soil acidity. Actually, most of sugarcane farms in the country are acidic that is why, one of the SRA's priority programs at this point is on soil rejuvenation. Soil $\mathrm{pH}$ also plays an important role in the availability of nutrients essential for plant growth. The major nutrients NPK are not available in highly acidic soils. Information on soil pH (soil acidity) can also be known in soil test.

The least training need identified under this area was on sugar regulation. "Quedans" are perceived to be negotiable instruments used in trading and not the physical sugar. Most sugarcane farmers especially the small ones are not aware on how their sugar "quedans" are being sold as trading is being handled by their cooperatives/associations.

\section{Business management}

Table 7 revealed that the respondents would like to know the current situation of the Philippine Sugarcane Industry being the major source of their income. Also, how the supply and demand of sugar in the world market is influencing the pricing of sugar in the country. However, the respondents expressed a limited need for training in accessing credit and record keeping which reflects the effect of the information drive on the SIDASocialized Credit Program being conducted recently by SRA. Financial literacy training is included in the program where farm record keeping is one of the subject matters. It is important that farm records be kept in order for farmers to be able to monitor and evaluate the performance of their crop production and make wellinformed decisions about their farm enterprises.

Table 7. Training needs of respondents in business management.

\begin{tabular}{lccccccc}
\hline Area & $\mathrm{N}$ & $\begin{array}{c}\text { Not } \\
\text { Needed }\end{array}$ & $\begin{array}{c}\text { Fairly } \\
\text { Needed }\end{array}$ & $\begin{array}{c}\text { Most } \\
\text { Needed }\end{array}$ & Score & $\begin{array}{c}\text { Weighted } \\
\text { Mean Score }\end{array}$ & Rank \\
\hline 1. Farm Plan and Budgeting & 112 & 0 & 27 & 85 & 309 & 2.76 & III \\
2. Record Keeping & 112 & 3 & 40 & 69 & 290 & 2.59 & V \\
3. Access to Credit & 112 & 4 & 39 & 69 & 289 & 2.58 & VI \\
4. World Sugar and How It & 112 & 4 & 18 & 90 & 310 & 2.77 & II \\
Affects Domestic Markets & 112 & 3 & 19 & 90 & 311 & 2.78 & I \\
5. Philippine Sugarcane Industry & 112 & 5 & 26 & 81 & 300 & 2.68 & IV \\
6. Sugar and By-products & & & & & & & \\
\hline
\end{tabular}

\section{Place of training preferred}

The respondents stated that they preferred to hold the training in the Barangay Hall, followed by function hall/hotel and then the MDDC training room (Table 8).
Barangay hall was preferred because farmers could easily reach the place of training since it was organized within their village. It also eliminates the problem of transport.

Table 8. Venue of training.

\begin{tabular}{lccccc}
\hline \multirow{2}{*}{ Venue of training } & \multicolumn{3}{c}{ Ranking (May only choose 3 venues per } \\
& \multicolumn{3}{c}{ Read, N<112) } & Rank \\
\cline { 2 - 4 } & 1st & 2nd & 3rd & III \\
\hline 1. MDDC office & 24 & 26 & 19 & \\
2. Planters' cooperative/Association's meeting area & 1 & 14 & 34 & I \\
3. Barangay Hall & 51 & 27 & 5 & \\
4. Farmer leader's residence & 7 & 8 & 0 & II \\
5. Function Hall/Hotel & 29 & 2 & & \\
\hline
\end{tabular}

\section{Months of training preferred}

The respondents stated that they preferred to attend training in the months of May, November and December (Table 9). The milling season in Davao starts in January and usually ends in April. Thus, May till December is when farmers are not busy in the farm and have enough time to attend to other activities such as trainings, seminars and farmers fora. 
Table 9. Month of training preferred.

\begin{tabular}{lccc}
\hline Month & Count & Percentage & Rank \\
\hline January & 1 & $0.89 \%$ & \\
February & 0 & $0.00 \%$ & \\
March & 0 & $0.00 \%$ & \\
April & 4 & $3.57 \%$ & I \\
May & 31 & $27.68 \%$ & \\
June & 9 & $8.04 \%$ & \\
July & 3 & $2.68 \%$ & \\
August & 3 & $2.68 \%$ & \\
September & 3 & $2.68 \%$ & \\
October & 3 & $4.46 \%$ & II \\
November & 26 & $23.21 \%$ & \\
December & $27.11 \%$ & \\
Total & 112 & $100.00 \%$ & \\
\hline
\end{tabular}

\section{Duration of training preferred}

Majority (around 51\%) of the respondents preferred one-day training and half-day however in the morning (Table 10). The respondents since being pre-occupied doing both productive and reproductive work would not have much time to spend for other activities. Spending much time would hinder their routine work. Time specific farm operation may suffer. This may be the reason for preference of training by respondents for less than a day.

Table 10. Duration of training preferred.

\begin{tabular}{lccc}
\hline Duration & Count & Percentage & Rank \\
\hline Half-day morning & 25 & $22.32 \%$ & II \\
Half-day afternoon & 14 & $12.50 \%$ & IV \\
1 day & 57 & $50.89 \%$ & I \\
2 days & 16 & $14.29 \%$ & III \\
Total & 112 & 100 & \\
\hline
\end{tabular}

\section{Training methods preferred}

The respondents were asked to select the preferred training methods. Formal research lecture with the Mill District Officer/Agriculturists (field extension personnel) was the most popular method for receiving training, followed by formal research lecture with OPSI Core group (select research and extension personnel) and practical on-site technology demonstration (Table 11). Informal group discussion was ranked as the lowest. The findings on the preferred training method indicate that majority of the respondents preferred personal locals (Mill District Officer/Agriculturists) rather than outside trainers as they could converse freely. Moreover, farmers preferred more practical training methods to enhance their learning experience. More than half of the respondents also preferred formal research lecture with the Outreach Program of the Sugarcane Industry-OPSI Core group which indicates that a scientific way of sugarcane production is appreciated. Only few preferred the hand-to-hand distribution of comics ("Ang Tamang Pagtutubuhan"). Similarly, informal group discussion was not preferred. The respondents claimed that although informal group discussion promotes social relationship among themselves, most often, the information being talked about is incomplete which sometimes creates confusions and as a result, they may remain separate without any co-operation. 
Table 11. Training methods in order of preference.

\begin{tabular}{|c|c|c|c|c|c|}
\hline \multirow{2}{*}{ Training Methods } & \multirow{2}{*}{$\mathrm{N}$} & \multicolumn{3}{|c|}{$\begin{array}{c}\text { Preference (May have same answers in different } \\
\text { preference) }\end{array}$} & \multirow{2}{*}{ Rank } \\
\hline & & Not Preferred & $\begin{array}{l}\text { Fairly } \\
\text { Preferred }\end{array}$ & $\begin{array}{l}\text { Most } \\
\text { Preferred }\end{array}$ & \\
\hline 1.) Formal Research Lecture with OPSI Core Group & 112 & 53 & 5 & 54 & II \\
\hline 2.) Formal Research Lecture with MDO/Agri & 112 & 14 & 20 & 78 & I \\
\hline 3.) Informal Group Discussion & 112 & 91 & 13 & 8 & \\
\hline 4.) Practical On-Site Technology Demonstration & 112 & 71 & 10 & 31 & III \\
\hline 5.) Hand-to-hand Distribution of Comics & 112 & 75 & 8 & 29 & \\
\hline
\end{tabular}

\section{Relationship between socio-economic characteristics of respondents and their training needs.}

Data depicted in the Table 12 shows the regression estimates of the determinants of training needs among sugarcane farmers in the study area. The R2 value of $34 \%$ and the adjusted $\mathrm{R}^{2}$ value of 0.276 or $28 \%$ variability in training needs were explained by the independent factors. This implies that the selected socio-economic variables explain the behaviour of the interest of farmers in receiving training. The $F$ value of 5.23 was significant at $1 \%$ level indicating goodness of fit of the regression line. Only 3 variables were found significant. Some of the variables in the equation were included as they improved the explanatory power of the model.

Table 12. Results of regression analysis showing relationships between investigated variables.

\begin{tabular}{lcccc}
\hline Variables & Parameter Estimate & Std. Error & $\mathrm{t}$ & Sig. \\
\hline (Constant) & 2.051 & .154 & 13.340 & .000 \\
Age & $.005^{* *}$ & .003 & 1.719 & .089 \\
Sex & .068 & .057 & 1.196 & .234 \\
Years in school & .006 & .008 & .722 & .472 \\
Years in sugarcane farming & .001 & .003 & .300 & .765 \\
No. of trainings in the past 5 years & $-.048^{*}$ & .014 & -3.333 & .001 \\
Farm size & .002 & .003 & .523 & .602 \\
Dummy variable proxied for Tenurial Status (DTS = 1 if the & -.071 & .056 & -1.271 & .207 \\
farmer leased the farm, otherwise zero). & & & & \\
Access to extension services & .111 & .078 & 1.424 & .158 \\
Access to improved varieties & $.327^{* * *}$ & .060 & 5.454 & .000 \\
Access to tractor services & -.090 & .057 & -1.572 & .119 \\
\hline
\end{tabular}

* Significant variables at $\mathrm{p}<0.05$

The coefficient for age was positive and significant at $10 \%$ level of probability. This implies that the older the sugarcane farmers, the more training needs they have. This may also infer the receptiveness to farm innovations as farmers aged. The result supports the findings of Oyeyinka and Bolarinwa (2015) which implied that as cassava farmers get older, more training is required in the areas of need identified so as to keep them abreast of the latest development and improvement on cassava cultivars. However, this is in contrast with the findings of Pierre-André et al. (2010) who used a sample of farmers from the South-west region of Cameroon and observed a negative relation between age and training needs on rubber production. The coefficients for years in school and number of farming experience were positive however, not significant. This implies that more educated and experienced farmers may take more risks in adopting new innovations thus, wanted to learn more knowledge and skills while farmers with a low level of education and less-experienced may take less risks thus uninterested to trainings. This proved the findings of Okwoche et al. (2015), who observed the positive relations between years in schooling and training needs of livestock farmers in Benue State, Nigeria.

The coefficient for the number of training attended for 
the past 5 years was negative and highly significant. This suggests that the higher number of trainings participated in by the farmers, the less the training needs. This is expected because farmers who have attended various trainings from the past five years have already gained knowledge and skills in the areas of need identified. This contradicts the findings of Adesoji et al. (2006) who concluded that the more the training attended before, the more the training needs of Fadama farmers in Nigeria. This is obvious in that if training attended meets the immediate needs of an individual, that individual would want more training so as to meet future needs.

The coefficient for farm size was positive but no significant impact on training needs. Big scaled-farm owners/operators seemed to need more knowledge in the areas of need identified training in order to be more productive and efficient. This conforms the findings of Owona Ndongo et al. (2010) which showed that the size of rubber farmland had a positive but no significant impact on farmers' training needs. Large farms desire to acquire knowledge in order to improve their production and be able to pay for farm inputs such as the hired laborers.

The coefficient for tenurial status was negative and also not significant. This infers that farmers who lease land for farming have lesser training needs than the landowners. This may be related to land ownership. Empirical evidence suggests that farmers who lease land for farming are less likely to invest in land improvement activities (Abdulai et al. (2011). This may be due to lack of security and absence of sufficient incentives for and returns from investment, thus farms operated by lessors run inefficiently (Otsuka and Hayami (1988). Land ownership is likely to raise investments and so with the farmers' training needs for the efficient use of farm inputs and improved technology.

The coefficient for access to high yielding planting materials was positive and highly significant at $1 \%$ level of probability. This implies that any increase in the access of high yielding planting materials will lead to increase in training needs among the farmers in the study area. This is expected as sugarcane farmers need knowledge and skills on how to select and grow the new varieties.

Therefore, the result of the hypothesis which states that the socio-economic characteristics of sugarcane farmers do not influence their training needs is rejected.

\section{CONCLUSIONS AND RECOMMENDATIONS}

A number of training needs in the survey area was identified which indicates a gap in farmer's knowledge and actual information. This needs to be addressed through designing and developing a training module. The SRA and the Davao MDDC can re-orient their training schedule and subject matter based on the findings to deepen farmer's knowledge on improved farm production technologies in sugarcane farming.

Farmers' high need for training on fertilizer and soil fertility management could be attributable to the recent quest for soil rejuvenation by the Philippine Department of Agriculture. Therefore, a training module should be developed on soil and nutrient management for sugarcane production. In the training schedule, the following should be included: types of fertilizers, computation, proper application to increase fertilizer use efficiency, trash mulching and the application of mudpress to increase organic matter in the soil, soil nutrients (NPK) and its mobility as plant grows and soil $\mathrm{pH}$ as it influences the availability of nutrients in the soil. Farmers' need for training on the selection of variety especially on the drought/water resistant variety could be due to the detrimental effect brought about by climate change in sugarcane farming. Thus, a training module should be developed for Variety Selection with consideration to choosing the varieties with high yield, disease resistance and adaptable in the district. Improper choice of the variety would result in low productivity, even when adequate quantities of inputs are applied.

A training module should also be developed on care and maintenance for sugarcane to cover weed and disease management. The former, with more focus on the development of an integrated weed control management. While in managing disease control, emphasis should be on the cultural practices as expressed by the farmers. These include planting of resistant varieties, using clean seedpieces, treating seedpieces, practicing good farm hygiene by minimizing the incidence of alternate hosts such as the coarse grass, and rogueing and burning of infected stools.

A training module on how to increase accumulation of sugar in the crop is also worth recommending. Actually, there are many techniques, but for Davao mill district, seizing fertilizer and irrigation before harvesting should be given attention. No $\mathrm{N}$ fertilizer should be applied a few months before harvesting for plants to mature and 
become ripe. Likewise, withholding irrigation before harvesting is also important for inducing maturity in sugarcane by reducing the rate of vegetative growth, dehydrating the cane and forcing the conversion of total sugars to recoverable sucrose. Imposing water stress during the maturation phase increases sucrose yields. A mill tour should be included in the training program coupled with lecture on sugar processing. The production sharing system in the district should also be taught to the farmers. Training schedule should include the current situation of the sugarcane industry in the domestic and world markets as this may contribute to their decision-making in their farming business.

Farmers also gave preference to other livelihood activities such as food processing for sugar-based byproducts such as muscovado sugar, vinegar and wine making and raising of other crops as training needs to undertake diversified agricultural activities since it may supplement family income. Therefore, training schedules for livelihood programs should include the development of product quality, product packaging and marketing. These technologies could be sourced from the Department of Science and Technology. While for raising other crops, technology on swine, corn, poultry and cattle production must also be disseminated to the farmers. Training modules on these technologies could be taken from the Bureau of Plant Industry and Bureau of Animal Industry.

Most of the training activities should be provided in the months of May, November and December before the start of milling when farmers are not busy in the farm and have enough time to attend such activities. Most of the sugarcane farmers preferred one-day training and half day however, in the morning and to be conducted at the Barangay Hall. Farmers prefer more practical training methods to enhance their learning experience although some farmers also preferred formal research lecture with the OPSI Core group which indicates that a scientific way of sugarcane production is also appreciated.

Abdulai, A., V. Owusu and R. Goetz. 2011. Land tenure differences and investment in land improvement measures: Theoretical and empirical analyses. Journal of Development Economics, 96: 66-78.

Adesoji, S. A., A. J. Farinde and O. A. Ajayi. 2006. Assessment of the Training Needs of Fadama Farmers for Future Agricultural Extension Work
The study concludes that there were significant relationships between farmers' characteristics and their training need. Variables such as age, the number of trainings attended in the past 5 years and access to HYVs were found significant to explain farmers' training needs. Training could be effective by targeting older farmers because they seemed to be more receptive to technologies although young farmers also need to be trained due to succession in sugarcane farming. Training should be provided to those farmers with few or no training at all to increase their knowledge and skills.

The study also recommends to assess the interventions given to the Davao MDDC particularly the nursery farms under the Rapid Propagation and Distribution Program of SRA especially on the accessibility of HYV seeds. One way to induce farmers to adopt improved technology is by making it accessible. Padilla-Fernandez and Nuthall (2001b) observed that the difference in the adoption of modern technology by the large farms and the small farms is not caused by the technology itself, it being neutral to farm size, but in the differences in the degree of access to modem technology. It also recommends for SRA and the Davao MDDC to increase extension contact and develop training modules and re-orient training schedules with training needs expressed by the farmers to improve the farm practices and productivity in the study area.

\section{ACKNOWLEDGEMENTS}

The authors thank the DMMC Chairman Constancio Gallinato and to the Davao Mill District office, most especially Mr. Edgar Aclao, Mill District Officer and his staff Mr. Resty Obiso, Ms. Jocelyn Nacua, Mr. Joey Tanduyan, Mr. Ronald Ordaneza and Mr. Jerick Aclao for facilitating the data gathering in translating the interviews to the local dialect and to the Sugar Regulatory Administration for the funding of the study.

\section{REFERENCES}

Development in Osun State, Nigeria. Journal of Applied Sciences, 6: 3089-95.

Ahmad, M., M. A. Jadoon, I. Ahmad and H. Khan. 2007. Impact of trainings imparted to enhance agricultural production in district Mansehra. Sarhad Journal of Agriculture, 23: 1211.

Chi, T. T. N. and R. Yamada. 2002. Factors affecting farmers' adoption of technologies in farming 
system: A case study in Omon district, Can Tho province, Mekong Delta. Omonrice, 10: 94-100.

DMDR. 2019. Davao Mill District ReportSugar Regulatory Administration. Quezon City, Metro Manila.

Huluka, A. T. and W. Negatu. 2016. The Impacts of Farmer Field School Training on Knowledge and Farm Technology Adoption: Evidence from Smallholder Maize Farmers in Oromia, Ethiopia. Journal of Economics and Public Finance, 2: 1.

Ibitoye, S. J. and J. A. Onimisi. 2013. Influence of Training on Farmer's Productivity in Poultry Production in Kogi State, Nigeria. International Journal of Poultry Science, 12: 239-44.

Kilpatrick, S. 2000. Education and training: Impacts on farm management practice. The Journal of Agricultural Education and Extension, 7: 105-16.

Kshash, B. 2016. Training Needs Of Rice Farmers In Mahanawiyah District, AL-Qadisiya Province, Iraq. Turkish Journal of Agriculture - Food Science and Technology, 4: 1072.

Mendoza, T. C., R. Samson and T. Helwig. 2001. Evaluating the many benefits of sugarcane trash farming systems. Philippine Journal of Crop Science, 27: 43-51.

Noor, K. B. M. and K. Dola. 2011. Investigating training impact on farmers' perception and performance. International Journal of Humanities and Social Science, 1: 145-52.

Okwoche, V., O. Abu and F. Hon. 2015. Analysis of training needs by livestock farmers in Benue state, Nigeria. European Journal of Research in Social Sciences, 3: 55-60.

Otsuka, K. and Y. Hayami. 1988. Theories of Share Tenancy: A Critical Survey. Economic Development and Cultural Change, 37: 31-68.

Owona Ndongo, P. A., A. Nyaka Ngobisa, E. E. Ehabe, B. Chambon and J.-C. Bruneau. 2010. Assessment of training needs of rubber farmers in the Southwest region of Cameroon. African Journal of Agricultural Research, 5: 2326-31.
Oyeyinka, R. and K. Bolarinwa. 2015. Training Needs of Cassava Farmers in Egbeda Local Government Area of Oyo State, Nigeria. International Journal of Agricultural Economics \& Rural Development, 7: 75-80.

Padilla-Fernandez, M. D. and P. L. Nuthall. 2001a. Farmers' goals and efficiency in the production of sugar cane: the Philippine case.

Padilla-Fernandez and Nuthall. 2001b. Input use inefficiencies in the production of sugar cane in Central Negros Area, Philippines: an application of data envelopment analysis.

Pagtutubuhan, A. T. 2019. Sugar Regulatory Administration, Quezon City, Metro Manila.

Raza, M. H., B. Shahbaz and M. A. Bell. 2017. Review based analysis of adoption gap and training needs of farmers in Pakistan. International Journal of Agricultural Extension, 4: 185-93.

Report, S. C. E. 2020. Sugar Regulatory Administration, Quezon City, Metro Manila.

Sajeev, M. V., A. K. Singha and V. Venkatasubramanian. 2012. Training Needs of Farmers and Rural Youth: An Analysis of Manipur State, India. Journal of Agricultural Sciences, 3: 103-12.

Trondillo, M. J. F., I. C. Generallao, R. A. R. Valleser, M. T. Lopez, A. Z. Janson, J. A. Bejarasco and I. R. Toriales. 2019. Identifying suitable sites for pump irrigation system from open source and shallow tube well in selected areas of Davao Del Sur through geographic information systembased water resources assessment. IOP Conference Series: Materials Science and Engineering, 527: 012043.

Wageningen Workshop Proceedings (2000). Adoption of Technologies for Sustainable Farming Systems., The Netherland's Ministry of Agriculture, Nature Management and Fisheries, Wageningen. https://www.oecd.org/greengrowth/sustainabl e-agriculture/2739771.pd

Publisher's note: EScience Press remains neutral with regard to jurisdictional claims in published maps and institutional affiliations.

Open Access This article is licensed under a Creative Commons Attribution 4.0 International License. To view a copy of this license, visit http://creativecommons.org/licenses/by/4.0/.

(C) The Author(s) 2020. 